зенской области (на примере двух урочищ «Большая ендова» и «Малая ендова» // Известия Самарского научного центра РАН. 2016. Т. 18, № 5. С. 112-117.

16. Красная книга Российской Федерации (растения) / гл. редкол. Ю.П. Трутнев и др.; сост.: Р.В. Камелин и др. М.: Т-во научных изданий КМК, 2008. $855 \mathrm{c}$.

17. Красная книга Самарской области. Т. 1. Редкие виды растений, лишайников и грибов / под ред. чл.-кор. Г.С. Розенберга и проф. С.В. Саксонова. Тольятти: ИЭВБ РАН, 2007. 372 с.
18. Плаксина Т.И. Редкие и исчезающие растения Самарской области. Самара: Самарский университет, 1998. 272 c.

19. Плаксина Т.И. Конспект флоры Волго-Уральского региона. Самара: Самарский университет, 2001. $388 \mathrm{c}$.

20. Саксонов С.В., Сенатор С.А. Путеводитель по Самарской флоре (1851-2011). Флора Волжского бассейна. Т. 1. Тольятти: Кассандра, 2012. 511 с.

Работа выполнена при поддержке РФФИ, проeкm № 16-44-630414 p_a.

\title{
VEGETATION OF THE NATURAL MONUMENT «GUREV RAVINE» (SHIGONSKY DISTRICT OF THE SAMARA REGION)
}

Novikova Lubov Alexandrovna, doctor of biological sciences, professor of General Biology and Biochemistry Department Penza State University (Penza, Russian Federation)

Saksonov Sergey Vladimirovich, doctor of biological sciences, professor, acting director, head of Phytodiversity Problems Laboratory

Vasjukov Vladimir Mikhailovich, candidate of biological sciences, researcher of Phytodiversity Problems Laboratory

Gorlov Sergey Evgenyevich, postgraduate student of Phytodiversity Problems Laboratory

Senator Stepan Aleksandrovich, candidate of biological sciences, senior researcher of Phytodiversity Problems Laboratory

Institute of Ecology of the Volga River Basin of Russian Academy of Sciences

(Togliatti, Samara Region, Russian Federation)

Solovieva Vera Valentinovna, doctor of biological sciences,

professor of Chair of Biology, Ecology and Methods of Teaching

Samara State University of Social Sciences and Education (Samara, Russian Federation)

Abstract. The nature monument of regional value «Gurev ravine» is located $1 \mathrm{~km}$ North-West village Klimovka of Shigonsky District in the Samara Region. The southern and South-Western part is occupied by the ravine, the mouth opening in the Kuibyshev reservoir. The right slope is less steep and is overgrown with deciduous forest, and the left slope is very steep and heavily nude, known as Gusikha mountain. At the mouth of the ravine as well as along the indigenous coast landslide terraces have been formed. We have described calciphyte flora and vegetation of the left slope, «Guriev ravine» (Gusikha mountain). We have made 5 descriptions, one (description № 14) is located at the bottom of this mountain and the other ones are at the top (descriptions № 15-18). All descriptions are made on very steep slopes (angle of $40-50^{\circ}$ ) of South-Eastern exposure. The described area is dominated by subshrub vegetation with dominance of different species: Artemisia salsoloides (from 1,0 to 30,0\%), Ephedra distachya (from 0 to 30,0\%), Bassia prostrata (from 0 to 15,0\%), Thymus dubjanskyi (from 0 to 15,0\%), Onosma volgensis (from 0 to 15,0\%), Anthemis trotzkiana (from 0 to 5,0\%); less common Linum uralense (from 0 to 1,0\%). Artemisia salsoloides (descriptions № 14, 16) occupy the lower and middle parts of the steep slopes of Gusikha mountain. They belong to two different associations. At the bottom of the slopes there are Artemisia salsoloides + Bassia prostrata + Gypsophila juzepczukii, in the middle - Artemisia salsoloides + Onosma volgensis. At the top of steep slopes there are Bassia prostrata, Ephedra distachya and Thymus dubjanskyi (descriptions № 15, 17, 18): Bassia prostrata + Artemisia salsoloides + Stipa capillata, Ephedra distachya + Artemisia salsoloides + Bassia prostrate and Thymus dubjanskyi + Anthemis trotzkiana + Gypsophila juzepczukii Association. Different types of Stipa capillata gradually implemented into the community as well as Gypsophila juzepczukii or Artemisia salsoloides, Anthemis trotzkiana, which contributes to the resumption of these particularly rare for the Samara Region species.

Keywords: vegetation; natural monument «Gurev ravine»; Gusikha mountain; Shigonsky District; Samara Region; Middle Volga biosphere reserve; Red book; Anthemis trotzkiana; Artemisia salsoloides; Gypsophila juzepczukii; Thymus dubjanskyi.

УДК 595.768.12

Статья поступила в редакцию 01.03.2018

\section{ДИНАМИКА ПЛОТНОСТИ ЖУКОВ-ЛИСТОЕДОВ (COLEOPTЕRA, CHRYSOMELIDAE) В АГРОЦЕНОЗАХ ЗЛАКОВЫХ КУЛЬТУР САМАРСКОЙ ОБЛАСТИ}

(C) 2018

Павлов Сергей Иванович, кандидат биологических наук, доцент кафедры биологии, экологии и методики обучения

Яицкий Андрей Степанович, старший преподаватель кафедры биологии, экологии и методики обучения Самарский государственный социально-педагогический университет (г. Самара, Российская Федерация)

Аннотация. В течение 1974-2010 гг. в зоне левобережной лесостепи Поволжья на полях злаковых культур Самарской области, в природных условиях и садках, изучались динамика развития растений озимой и 
Павлов С.И., Яицкий А.С.

яровой пшеницы, генерационные циклы 6 местных видов жуков-листоедов с 1-годичным развитием (пять из которых серьезно вредят пшенице (пьявица красногрудая Oulema melanopus L., блошка полосатая хлебная Phyllotreta vittula Redt., блошка стеблевая большая Chaetocnema aridula Gyll., блошка стеблевая обыкновенная Chaetocnema hortensis Geoffr., шипоноска черная Hispella atra L.) и один (щитоноска бодяковая зеленая Cassida rubiginosa Müll.) является потребителем сорного растения - бодяка полевого Cirsium arvense (L.) Scop.); изучалась также динамика плотности листоедов и их локализация на посевах зерновых разного возраста. Изучен микроклимат агроценозов злаковых при разных погодных режимах, разной интенсивности вегетации обследуемых растений, в разное время суток. Рассмотрены важнейшие этапы генерации вредящих видов листоедов и сроки их реализации: выход зимовавших жуков из их укрытий и расселение на посевы, питание созревания, агрегирование и спаривание, период яйцекладки и его продолжительность, сроки, возраста развития и местообитание личинок, сроки окукливания и продолжительность формирования жуков нового поколения. Анализируются степень и сроки вредоносности разных листоедов; обсуждается хозяйственное значение отдельных их видов. Обозреваются условия, предпочитаемые вредителями продовольственной пшеницы, факторы, угнетающие их преимагинальные стадии, рассматриваются случаи образования массовых скоплений жуков и личинок и миграций листоедов на более комфортные участки. Делается вывод об исключительной пластичности и приспособляемости листоедов к микроклиматическим условиям обитания.

Ключевые слова: жуки-листоеды; Chrysomelidae; пьявица красногрудая; Oulema melanopus L.; блошка полосатая хлебная; Phyllotreta vittula Redt.; блошка стеблевая большая; Chaetocnema aridula Gyll.; блошка стеблевая обыкновенная; Chaetocnema hortensis Geoffr.; шипоноска черная; листоед шиповатый; Hispella atra L.; щитоноска бодяковая зеленая; Cassida rubiginosa Müll.; вредители; агроценозы; генерационные циклы; динамика плотности; злаковые культуры; пшеница; овес; ячмень; Самарская область; Среднее Поволжье.

\section{Введение}

Жуки-листоеды «самым тесным образом связаны с растительностью. Их важнейшей экологической особенностью является узкая трофическая специализация, т.е. связь конкретных видов с определенными таксонами растений» [1, с. 3].

Из всей фауны жуков семейства Chrysomelidae в Среднем Поволжье (в том числе в Самарской области) с растениями, активно используемыми человеком для своих пищевых и хозяйственных нужд, связано 36 видов. Из них вторичными (но подчас весьма серьезными) вредителями зерновых культур являются 5 видов листоедов и еще 1 вид (тоже встречающийся на хлебных полях) - активный потребитель сложноцветных сорняков. По данным В.Г. Каплина и др. [2, с. 6-11], ткани злаковых растений слабо освоены личинками листоедов местной фауны, достаточно сказать, что в Европе выявлено 11 вредящих видов.

Цель нашей работы - анализ экоклиматических условий вегетации пшеницы в Самарской области и «вписанных» в отдельные стадии ее развития биологических этапов генерации вредящих видов жуковлистоедов, обзор динамики локации и плотности листоедов на посевах разного возраста.

Материал собран нами в 1974-2010 гг. на территории Волжского, Исаклинского, Кинельского и Красноярского районов Самарской области.

\section{Методика исследования}

Используя как эталон шкалу Дж. Задокса, мы с помощью соответствующих методик [3] отследили особенности развития пшеницы в местных условиях; для изучения биологии и экологии ее потребителейнасекомых были применены классические энтомологические методики; наблюдение за трофическим поведением листоедов проводилось в садках.

\section{Результаты исследования и их обсуждение}

Следует заметить, что за весь 7-8-тысячелетний путь эволюции пшеницы как важнейшего пищевого продукта происходила коадаптация растения и его консументов [4, с. 43-92]. Поэтому минимальная и даже средняя численность вредящих насекомых не угнетает, а, напротив, стимулирует развитие растения-продуцента. И только уровень, превышающий оптимальный баланс сил, наносит значительный ущерб. Отношениям в тандеме «пшеница-потребители» посвящено более 150 работ, из которых нами использовано 12.

Стадии развития яровой пшеницы (приводятся по Задоксу [3], с некоторыми авторскими дополнениями).

Вегетация - состояние активизации растений злаковых, сопровождающееся их активным ростом и развитием в течение 91-92 суток.

Появление всходов - 1-й этап стадии развития зародышевого побега (при оптимальных условиях обычно на 10-й день).

Зеленение (развитие зародышевого побега) осуществляется, когда листовые зачатки разрастаются и листья обнажаются (последовательные этапы появления 1-го, 2-го и 3-го листа на 11-й, 12-й и 13-й день развития). Листья злаковых растений сидячие, простые (с влагалищами, обхватывающими стебель), цельнокрайные, линейные с параллельным жилкованием.

Кущцение - образование надземных боковых побегов (и в результате плотного куста, включающего 10 и более листьев) из узла, расположенного у основания главного побега. Включает следующие этапы: начало стадии - с 21-го, основное кущение - с 26-го и законченное кущение к 30-му дню. У озимых культур, при оптимальных условиях (температуре приземного слоя воздуха $+10 \ldots+15^{\circ} \mathrm{C}$ ), закладывается 3 6, у яровых - 2-3 побега.

Стеблевание - стадия развития хлебного злака, характеризующаяся удлинением его стебля, т.е. удалением друг от друга узлов, которое осуществляется параллельно с ростом листьев и вытягиванием в длину междоузлий, в результате чего образуется стебель-соломина (цилиндрический, полый в междоузлиях и имеющий перегородки в узлах). Стеблевание 
включает 5 этапов: начало процесса - с 30-го дня, образование 1-го узла - с 31-го дня, образование 2-го узла - с 32-го дня, появление последнего листа - с 37-го дня и, наконец, этап появления пленчатого язычка - на 39-й день. Язычок расположен в месте отхождения листовой пластинки от листового влагалища и препятствует попаданию воды из окружающего пространства в полость между стеблем и влагалищем листа.

Выход в трубку - этап резкого (в течение 8 дней) удлинения стебля, начинающегося, при «стандартных» климатических параметрах, с 40-го дня развития. Первым растет и удлиняется самое нижнее междоузлие, расположенное практически над узлом кущения. Наиболее интенсивный рост этого участка продолжается 5-7 дней, затем ослабевает и заканчивается на 10-15-й день. Почти одновременно с ним (запаздывая на 1-2 дня) начинает удлиняться 2-е снизу междоузлие. После приостановки его роста усиленно развивается 3-е междоузлие, обгоняя по срокам 2-е. Стадия выхода в трубку продолжается до тех пор, пока не образуется 5-6 подобных участков. Поскольку каждое междоузлие растет своей нижней частью, то верхний его сектор, сформированный чуть ранее, раньше и твердеет, а нижняя (растущая) часть междоузлия долго остается мягкой и нежной.

Флаговый лист - этап раскрытия последнего листового влагалища (на 47-й день развития) и появления верхнего (ближайшего к колосу) листа, расположенного выше других, имеющего самую большую площадь листовой пластинки и максимальную фотосинтетическую активность (до $45 \%$, в отличие от нижнего листа, создающего только $10 \%$ органического материала), обеспечивающего колос и будущие зерновки питательными веществами.

Колошение (у овса - выметывание соцветий) стадия развития злакового растения, характеризующаяся выходом его соцветия из влагалища верхнего листа, включает 3 этапа: начало - с 51-го, середину с 55-го и конец колошения - к 59-60-му дню.

Цветение - комплекс генеративных процессов, протекающих от момента заложения цветка до собственно оплодотворения. Стадия продолжается в течение 10 дней и включает 3 этапа: начала - с 61-го, полного цветения - с 65-го и окончания процесса - к 70-му дню.

Созревание - ряд изменений в зерне, в результате которых оно становится полноценной диаспо́рой (носителем наследственной информации), а околоплодник готов выполнять функции по ее защите и расселению. Эта стадия развития (длящаяся 20-21 день) включает 5 этапов: образования зерна (водяную спелость) - с 71-го, молочную спелость - с 75го, восковую - с 85-го, желтую - с 87-го дня и полную спелость - к 91-92-му дню.

Разумеется, что нами рассмотрена некая идеальная схема, зависящая от совокупности благоприятных обстоятельств. В действительности же сроки развития яровой пшеницы могут колебаться от 91 до 100 суток, накапливая по 1-2 суткам на каждой возрастной стадии. Так, по нашим наблюдениям, при температуре воздуха $+8 \ldots+10^{\circ} \mathrm{C}$ продолжительность времени от посева до появления всходов составляет 10-12 суток, а при температуре $+12^{\circ} \mathrm{C}$ - только 10 суток. Или, при запасах влаги в почвенном слое глубиной до 25 см менее 20 мм в период посева и при отсутствии осадков, после посева интервал времени до появления всходов увеличивается, а сами всходы бывают «недружными», что свидетельствует о значительной ослабленности растений.

Микроклимат (или экоклимат) злакового поля характерен определенным уровнем освещенности, нормой температур воздуха и почвы, влажности воздуха, запасов продуктивной почвенной влаги и количеством атмосферных осадков [4, с. 43-92]. Каждый естественный биогеоценоз обладает собственными механизмами, поддерживающими его гомеостаз. Для агроценозов как искусственных систем, запрограммированных на резкое повышение их биомассы, равновесие компонентов не свойственно. Тем не менее, оставаясь элементарными частицами биосферы, они испытывают влияние абиотической среды планеты и диких живых организмов - соседей по экологической нише [5, с. 184-189].

На начальном этапе вегетации (до стадии кущения), когда даже засеянное поле еще мало чем отличается от пара, основная солнечная радиация, падающая на землю и необходимая для испарения влаги с поверхности почвы и нагревания приземного воздуха, расходуется примерно поровну.

На стадии кущения, когда пшеничное поле уже сплошь покрыто растительностью (высотой в 1315 см), до 90\% поступающей энергии тратится на испарение влаги и только 10-15\% - на нагревание воздуха [6, с. 120-131]. Среднесуточная влажность воздуха в это время составляет около $58 \%$.

На стадии выхода в трубку, в мае, при высоте растений пшеницы 20 см, были [6, с. 120-131] проведены замеры температуры воздуха в пределах агроценоза пшеничного поля в 4 часа ночи, в $10,13,16$ и 19 часов светлого периода суток. Температура воздуха ночью у поверхности почвы составила $+12,4^{\circ} \mathrm{C}$, на высоте $2 \mathrm{~m}-+13,3^{\circ} \mathrm{C}$; в 10 часов соответственно $+28,6$ и $+22,4^{\circ} \mathrm{C}$, в 13 часов $-+41,4$ и $+24,1^{\circ} \mathrm{C}$, в 16 часов $-+33,8$ и $+24,2^{\circ} \mathrm{C}$, в 19 часов $-+21,6$ и $+20,0^{\circ} \mathrm{C}$.

После окончательного формирования растений пшеницы (достигших уже высоты 45-60 см), ее колошения и цветения, баланс расходования энергии на испарение и нагревание смещается в сторону лучшего обеспечения растения теплом, необходимым для скорейшего созревания зерновок. В этот период от 53 до 64\% энергии тратится на нагревание воздушной среды агроценоза и $36-47 \%$ - на процесс транспирации.

На финальном этапе органогенеза радиационный баланс достигает $66 \%$ - на нагревание среды и $34 \%$ на испарение. Листья растения высыхают, сводя уровень транспирации к минимуму. В результате воздух становится более сухим (относительная влажность снижается с 35 до $32 \%$ ) и теплым.

На засеянных полях не только растения препятствуют движению воздуха, но сам воздух, будучи более влажным и плотным, менее подвижен. Только 
Павлов С.И., Яицкий А.С

ветер со скоростью более 1,5 м/сек. способен вызывать колебания растений, а воздушные потоки 810 м/сек. - их полегание. Ветер свыше 2 м/сек. становится серьезным препятствием [7] для двигательной активности листоедов (особенно личинок младших возрастов) и снижает их вредоносность.

Биоэкологические очерки жуков-листоедов.

Пьявииа красногрудая, или обыкновенная (рис. 1) - Oulema melanopus L.

Жуки зимуют в почве (на глубине 15-25 см, т.е. 30-50 длин их корпуса) на окраинах полей, в лесополосах, на опушках лесных массивов, в опаде.

Появляются они в конце (в 15-25-х числах) апреля. Продолжительность фазы выхода имаго из мест зимовки составляет 7-20 суток. В этот период они широко расселяются по посевам яровых хлебов (предпочитая прочим овес, твердые сорта пшеницы и ячмень). Е.В. Гуськовой было замечено [8], что весной при заселении посевов (а также при перемещениях в границах одного поля или при переходе к питанию дикими злаками, после ухода с полей) жуки пьявицы мигрируют на небольшие расстояния целыми скоплениями.

Продолжительность полового созревания (в процессе дополнительного питания жуков) составляет 6-12 дней.

Ресурс плодовитости отдельной самки достигает 150-200 (реже - 300) яиц. Период яйцекладки продолжается более 1 месяца (40-45 дней). Кладка (из 3-7 яиц, соприкасающихся приостренными апикальными концами и таким образом собранных в «цепочку» - рис. 2) обычно помещается на нижней стороне листа злакового растения и всегда ориентирована вдоль длины листовой пластинки. Развитие эмбрионов продолжается в течение 12-14 суток.

Вышедшие личинки (первые из них появляются 10-20 мая) вредят яровым хлебам, выгрызая паренхимную ткань листьев, до начала колошения растений (примерно с 15 мая по 10 июня). Период максимальной вредоносности жуков и личинок продолжается 27-33 дней и приходится на отрезок времени от начала кущения растений пшеницы до их колошения. По наблюдениям [9], при степени повреждения листьев от 3,5 до 5,0 баллов уменьшалось число зерновок в колосе и заметно снижалась масса самих зерен. Исследования этих же ученых [4; 9] показали, что наиболее устойчивы к заселению пьявицей на стадии выхода в трубку сорта пшеницы, имеющие опушенность листьев по 30 и более волосков на $1 \mathrm{Mм}^{2}$. Чем интенсивнее питается личинка (что тоже во многом зависит от погодных условий среды), тем активнее она растет. По данным Н.Н. Горбунова и др. [10], средняя масса личинки в процессе развития (от 1-го возраста к 4-му) меняется от 0,064 до 1,502 мг, т.е. увеличивается примерно в 23,5 раза. За 15-20 дней развития каждая личинка проходит 4 возрастных стадии (занимающих около 3, 4, 5 и 6 дней соответственно).

Потом личинка окукливается в верхнем слое почвы (на глубине 2-4 см).
Через 13-15 дней отрождаются жуки нового поколения (которые, однако, остаются в почве до весны следующего года).

Нами установлено, что неблагоприятные погодные условия (низкие температуры воздуха, избыточная влажность, постоянные ветра) оказывают сильное тормозящее действие на развитие преимагинальных фаз пьявицы.

В течение сезона развивается только 1 поколение.

Блошка полосатая хлебная (рис. 3) - Phyllotreta vittula Redt.

Зимуют жуки на межах полей, бровках оврагов и балок, опушках лесополос, степных колков и сопредельных с агроценозами лесных массивов под листовым опадом в верхнем слое почвы (на глубине 812 см, т.е. 40-60 длин корпуса жука).

При благоприятных условиях (температуре воздуха $+4 \ldots+7^{\circ} \mathrm{C}$ ) они выходят из мест зимовки в конце марта - начале апреля. Первое время имаго кормятся на диких злаках (пырее, мятлике, житняке, мышее, овсянице и др.) и озимой пшенице. С появлением всходов яровых культур (пшеницы, ячменя, кукурузы, проса и овса - менее повреждаемого среди других злаков), жуки перелетают на их поля, где регистрировались нами уже в конце (с 18 числа) апреля - начале (до 6 числа) мая. Именно в этот период (в течение 18-22 дней) происходит массовое спаривание жуков, постепенно «затухающее» к его последней трети (с 5 по 12 мая).

Через 5-7 дней после спаривания самки откладывают яйца (по 1-3) в почву (на глубину 2-3 см) близ корней кормовых растений. Продуктивность одной самки колеблется от нескольких десятков до нескольких сотен яиц [11]. По нашим наблюдениям, весь процесс яйцекладки растянут почти на 50 дней мая-июня. Хорион яйца очень чувствителен к температуре почвы - в засушливые сезоны (при температуре свыше $+47 \ldots+52^{\circ} \mathrm{C}$ ) он подсыхает, становится плотным, и до $80 \%$ отложенных яиц гибнет [12, c. 128-130]; однако в «стандартные» годы вид склонен к образованию «очагов» массового скопления (до 106,5-122,3 ос./100 поврежденных растений).

Здесь, на яровых хлебах, численность половозрелых жуков постоянно нарастает и к началу июня достигает своего максимума (5-10 ос./раст.) при общей плотности насекомых в 80 и более ос./ $\mathbf{M}^{2}$. Площадь сельскохозяйственных угодий, заселенных хлебной блошкой, обычно колеблется в пределах 6,514,3 тыс. га. Однако регистрируются и «неожиданные всплески» численности: например, во время весеннего обследования 1961 г. посевных площадей Куйбышевской области была зафиксирована одна из самых значительных по протяженности территорий, заселенных данным вредителем: «до 22,6 тыс. га агроценозов с плотностью от единичных экземпляров

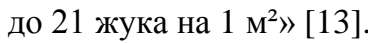

Отродившиеся через 5-8 суток из яиц личинки пребывают в верхнем слое почвы, где питаются вторичными корнями злаков, не нанося растениям при этом серьезного вреда. Взрослые личинки уплотняют вокруг себя почву, создавая в ней некий округлый земляной «кокон», внутри которого они и окуклива- 
ются. Число личиночных возрастов предположительно -4 .

Стадия куколки продолжается 13-15 суток.

Молодые жуки выходят во 2-й половине лета. После уборки урожая имаго новой генерации мигрируют на зимовку на участки, пространственно удаленные от территории бывших агроценозов зерновых.

В течение года развивается только 1 поколение.

Блошка стеблевая большая (рис. 4) - Chaetocnema aridula Gyll.

Зимуют жуки, которые после вылета из своих укрытий мигрируют на озимые хлеба, с появлением всходов яровых культур переселяются на них, предпочитая овес и пшеницу.

Самка откладывает яйца в ткань отмирающих прикорневых листьев или в колеоптиле (1-й влагалищный лист, не имеющий собственной листовой пластинки).

Появившаяся через 5-7 дней личинка внедряется в стебель, попадает в его внутреннюю полость. Обычно соломина злака полая, но у твердой пшеницы под колосом, а у ряда сортов мягкой пшеницы весь объем стебля заполнен сочной паренхимой. Кроме того, в основании каждого междоузлия (чуть выше стеблевого узла) расположена образовательная ткань, за счет интенсивного деления клеток которой и происходит рост растения. Именно этими тканями и питается личинка блошки, по мере взросления все более активизируя свою трофическую деятельность, чем сильно вредит растению.

Личинка развивается 14-20 дней, окукливается в почве.

Вылет молодых жуков начинается в начале июля. В первое время они держатся на яровых хлебах, а после уборки урожая мигрируют в леса, балки, где зимуют под листовым опадом.

Жуки питаются листьями злаковых растений (зелеными и на стадии их увядания), личинки живут внутри молодых стеблей (соломины) злаков, сильно повреждая их.

На территории Европейской части России (севернее линии, соединяющей города Балашов-СызраньЧелябинск [14]) серьезно вредит зерновым злакам (овсу и пшенице), а также - житняку, овсянице, пырею. Установлено [2, с. 96-114], что в лесостепи Самарской области большая стеблевая блошка по численности явно преобладает над обыкновенной стеблевой блохой, в том числе на яровой пшенице в среднем в 23, на озимой - в 16, на ячмене - в 7 раз.

Блошка стеблевая обыкновенная - Chaetocnema hortensis Geoffr.

Отличается от большой хлебной блохи тем, что самка откладывает яйца не в ткани листьев, а в почву у основания кормовых растений.

Зимуют жуки под листовым опадом в древесных массивах.

Нами замечено, что в засушливые сезоны (при температуре свыше $+36,3^{\circ} \mathrm{C}$ ), численность вредящего вида уменьшается иногда до $60 \%$, вероятно, это связано с гибелью от «теплового стресса» значительной части отложенных в почву яиц. Возможно также, что почва в месте яйцекладки была либо более плотной, либо, наоборот, более сыпучей, что препятствовало успешному закапыванию жуком яиц и создало условия для их высыхания [15, с. 202].

Личинка, как и в предыдущем случае, развивается внутри стебля злаков.

Массовые размножения наиболее обычны в лесостепной и реже - в степной зонах, в теплые влажные годы, а на поливных землях - в более сухие.

Из злаков предпочитает яровую пшеницу, ячмень, житняк.

Шипоноска черная, или листоед шиповатый (рис. 5) - Hispella atra $\mathrm{L}$.

Жуки зимуют в листовом опаде и лесной подстилке опушек лесополос и смежных с агроценозами лесных массивов. Весной они переселяются на степные участки, луга и поля зерновых культур. Этот этап занимает примерно 14-25 дней.

Живет на злаках, преимущественно луговых. Иногда жуки грызут листья пшеницы и других культурных злаков (не нанося растениям серьезного вреда).

Самка откладывает по 1 яйцу в ткани молодого листа кормового растения в верхней трети его листовой пластинки. Развитие яиц длится 4-6 дней.

Зарегистрировано 3 личиночных возраста [11], имеющих цилиндрические, несколько уплощенные дорсовентрально тела и слабые, короткие ноги. Личинки младших возрастов отличаются более светлой окраской и резче ограниченными склеритами. Длина тела взрослой личинки - до 6,0-6,5 мм. Личинки минируют листья злаковых растений (Poa и Agropyron). $\mathrm{B}$ каждой отдельной мине развивается 1 личинка. Мины узкие, более или менее вытянутые, длиной до 5 см. Внутритканевый ход прокладывается личинкой от вершины листа к его основанию (более устойчивой к сотрясениям части).

Личинка окукливается внутри мины. Куколка развивается в течение 14-18 суток. По наблюдениям агронома П.Ф. Хлыстова, начало выхода жуков нового поколения приходится на конец июня.

Следует заметить, что шипоноска довольно редка в Самарской области [16], вероятно потому, что находится на северной границе своего ареала.

Щитоноска бодяковая зеленая (рис. 6) - Cassida rubiginosa Müll.

Жуки зимуют в лесной подстилке, весной переселяются на опушки, луга, побережья водоемов, степные участки, в агроценозы.

Яйцекладка - в мае-июле (но пик процесса, по нашим наблюдениям, приходится на вторую половину мая). Яйца откладываются группами, реже поодиночке на нижней стороне листьев и покрываются специальной пленчатой капсулой - оотекой. Яйца продолговатые, заостренные с обоих концов, чуть уплощены дорсовентрально. Оотека образуется за счет быстро твердеющих выделений желез яйцевода. Число яиц в оотеке обычно - 2-9, сверху она маскируется плоским щитком из экскрементов. Развитие яиц длится 4-6 дней.

Вышедшие молодые личинки питаются на нижней стороне листьев. Характерной особенностью ли- 
Павлов С.И., Яицкий А.С

чинок является их способность камуфлировать свое тело сверху экскрементами, которые выделяются из подталкивателя на загнутые на спинную сторону хвостовые нити и вместе с экзувиями (линочными шкурками личинок младших возрастов) образуют компактный, бугровидный защитный щиток. Личиночная стадия длится 12-17 дней. Зарегистрировано 4 личиночных возраста. Кормясь по 3,7-4,0 час./день, за 85-120 приемов корма в течение всей генерации ли-

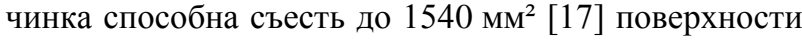
листьев питающего растения (что складывается из

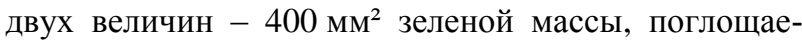
мых личинками младших, и 1140 мм², съедаемых личинками старших возрастов).

Стадия куколки длится примерно 12 суток. Выход молодых жуков начинается с конца июня. Весь генерационный цикл вида, по нашим наблюдениям, укладывается в 30-32 дней.

Жук и личинка скелетируют листья основных кормовых растений (бодяка, лопуха, репейника, чертополоха).

Жуки уходят на зимовку в августе.

Динамика локализации и плотности листоедов. Спектр видов насекомых периферийной части агроценозов характеризуется большим видовым разнообразием и высоким обилием. Например, поскольку экспансия бодяковой щитоноски в агроценозы, засоренные бодяком, осуществляется от периферии поля (граничащего с естественными растительными сообществами) к его центру, вполне естественно, что плотнее этим листоедом бывают заселены именно окраины полей (в радиусе 70-150 м), возвышенные участки рельефа и более загущенные сообщества сорняка (включающие более 45 раст. $/ \mathrm{M}^{2}$ ).

Свето- и теплолюбивые, а также толерантные к засухе и вредящие культурным злакам виды тяготеют к центральной части полей монокультур. Однако и здесь они распределены не равномерно, а в соответствии со своими экологическими и трофическими преференциями. Например, пьявица держится на посевах злаков отдельными «очагами», в границах которых нами регистрировалось массовое пожелтение и усыхание поврежденных листьев.

На посевах пшеницы доминирующую группу в мае составляют жуки-листоеды [18]: на них (при 50 взмахах сачком в 20-кратной повторности) пришлось 17,5 имаго (из которых 4 экз. пришлось на долю полосатой хлебной блошки), на остальные виды жуков - лишь 5,5 экз. В июле листоеды продолжали численно преобладать: теперь они составили 479,6 экз. (из которых 458,9 составили имаго полосатой блошки), на 4 экз. других видов жуков. На многих полях видовой спектр жуков в июле становится более разнообразным, чем в мае, но менее обильным, чем в смежных природных биотопах.

Первое время, после массового вылета на поля, жуки пьявицы (до 75\% популяции) группируются [19] в пониженных увлажненных местах с достаточно загущенной растительностью (рис. 7: $a$ ), избегая прямого действия холодного ветра, но уже через 17 25 дней, на стадии стеблевания пшеницы, жуки (ино- гда до 80-90\% популяции) перемещаются на более возвышенные, хорошо прогреваемые участки с умеренно разреженным травостоем (рис. 8: б).

Полосатая хлебная блошка максимально вредит растениям на стадии всходов и 3-го листа. Ущерб от вредителя особенно заметен на полях, бедных запасами почвенной влаги. Нами установлено, что полосатая хлебная блошка предпочитает незагущенные участки травостоя (где их численность в 2-3 раза выше, чем на более плотно засаженных местах). Кроме того, известно [20], что, кроме агроценозов, некоторое количество блошек остается на парах, залежах и сопредельных остепненных лугах, являясь своего рода резервом сохранения вида. Как показали наблюдения [21], примерно каждый 3-й год регистрируются массовые вспышки численности полосатой блошки.

Установлено [2, с. 96-114], что на полях, используемых ежегодно и бессменно, численность большой стеблевой блохи в 3 раза выше, чем на участках с естественным севооборотом (регулярной сменой полей и посевных культур).

На участках посевов, засоренных бодяком, где концентрируются личинки и жуки бодяковой щитоноски, бывает уничтожено [17] до 42\% поверхности листьев. Такие сообщества издали обычно выглядят не зелено-сизыми (как нормальные, неповрежденные), а серо-зелеными. Неоднократно (20.07.1975, 11.07.1982, 19.07.1997 и 30.06.2002) нами регистрировались уникальные по своей численности скопления личинок $C$. rubiginosa Müll. по 400-500 особей (12-18 особей на 1 листе, т.е. почти по 1 личинке на $\left.1 \mathrm{~cm}^{2}\right)$. В «очагах» подобных агрегаций было уничтожено до $88 \%$ растений бодяка.

В заключение следует отметить, что даже при попытках массированного агромеханического и химического воздействия на вредящих злаковым культурам насекомых их исключительная адаптивная пластичность позволяет им найти наиболее оптимальные экологические условия (нужное место и подходящее время) для успешного выживания.

Из пяти потенциально вредящих видов наиболее опасны пиявица красногрудая Oulema melanopus L., блошка полосатая хлебная Phyllotreta vittula Redt. (кормится на внешних частях растений) и блошка стеблевая большая Chaetocnema aridula Gyll. (личинка которой выскабливает жизненно важные ткани внутри стебля). Блошка стеблевая обыкновенная Chaetocnema hortensis Geoffr. менее распространена, присутствует спорадически, даже не на каждом поле. Что касается шипоноски черной Hispella atra L., то это редкий вид, находящийся на северной кромке ареала, потому неспособный причинять вред; он мог бы оказаться экономически значимым при численности в 20-25 раз большей. В отношении щитоноски бодяковой зеленой Cassida rubiginosa Müll. следует отметить, что это полезный для человека вид, заметно влияющий на рудеральные сложноцветные (именно поэтому либо предпринимались неоднократные опыты расселения щитоносок на засоренные поля, либо экспорт их за рубеж). 


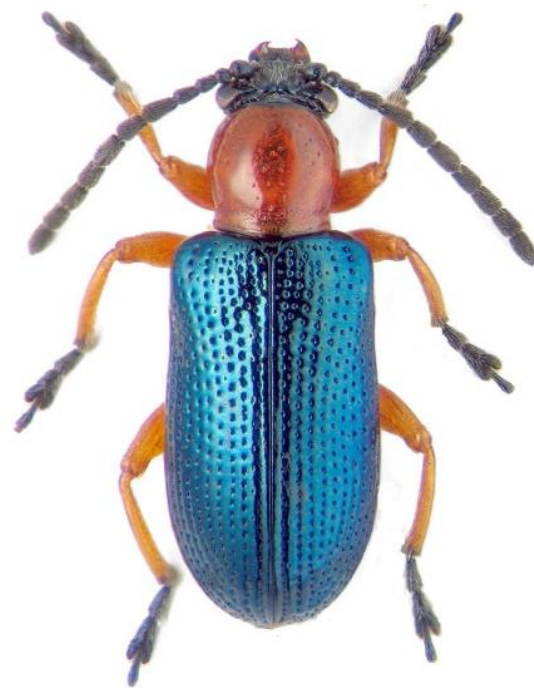

Рисунок 1 - Имаго пьявицы красногрудой Oulema melanopus L. (фото А.Л. Лобанова)

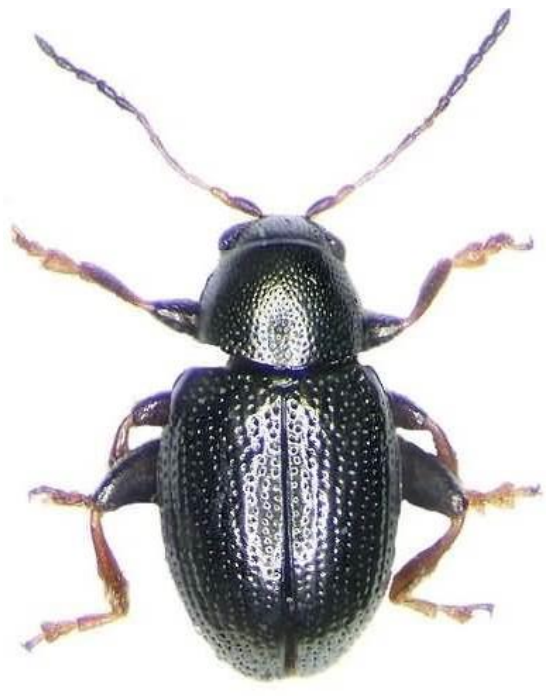

Рисунок 4 - Имаго

блошки стеблевой большой Chaetocnema aridula Gyll. (фото У. Шмидта)

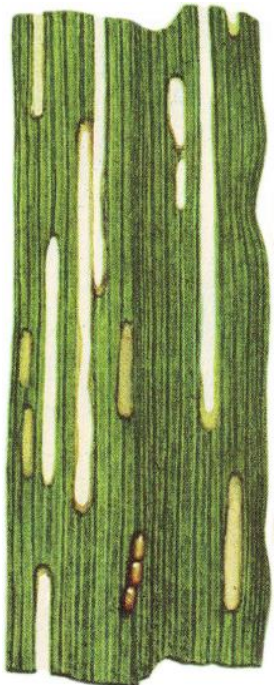

Рисунок 2 - Лист твердой пшеницы, поврежденной жуком пьявицы красногрудой Oulema melanopus L. (снизу - видна кладка из 3 яиц) (рис. А. Сэвеску)

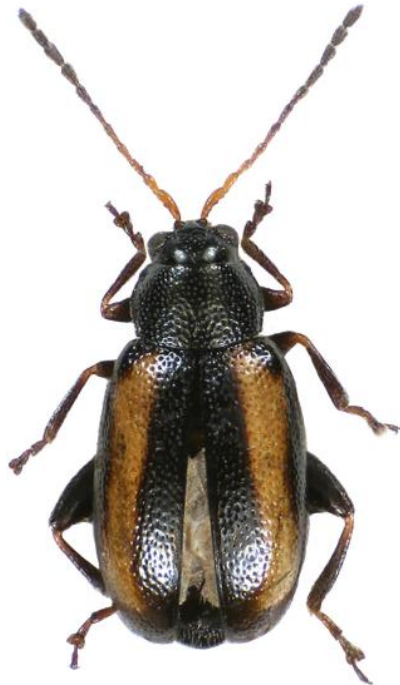

Рисунок 3 - Имаго

блошки полосатой хлебной Phyllotreta vittula Redt. (фото М. Демла)

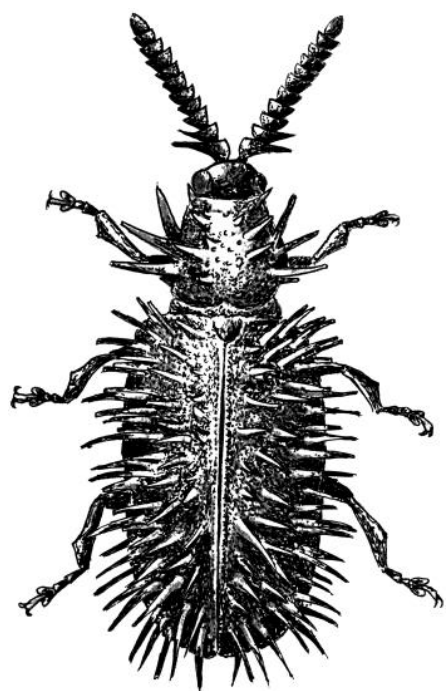

Рисунок 5 - Имаго шипоноски черной Hispella atra L. (рис. А.С. Тилли)

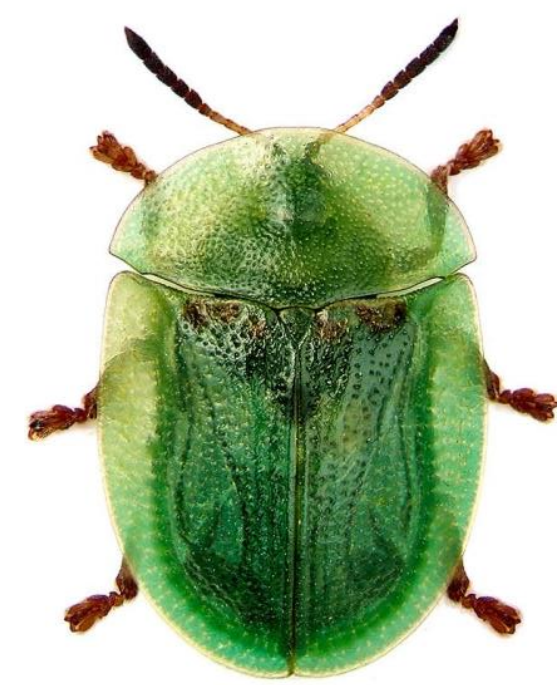

Рисунок 6 - Имаго

щитоноски бодяковой зеленой Cassida rubiginosa Müll. (фото К.В. Макарова)

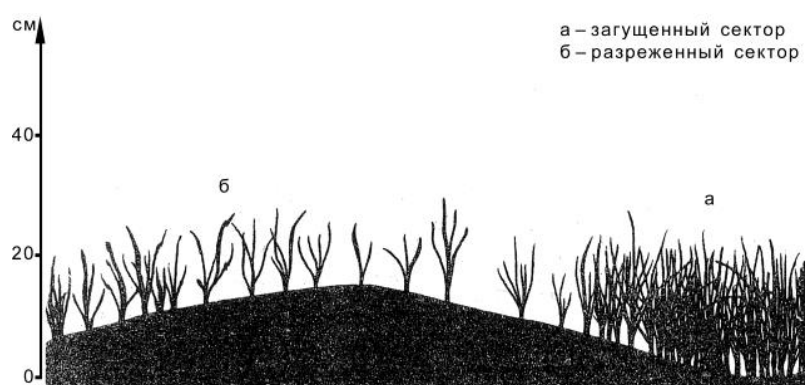

Рисунок 7 - Заселение пьявицей красногрудой Oulema melanopus L. пшеницы на стадии «всходов-кущения» (жуки концентрируются в загущенном секторе «а») (рис. С.И. Павлова)

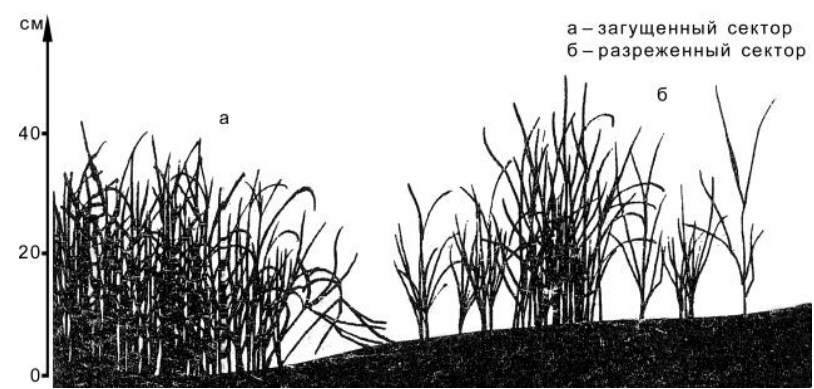

Рисунок 8 - Перегруппировка жуков пьявицы красногрудой Oulema melanopus L. на посевах на стадии их «стеблевания» в более разреженный и прогреваемый сектор «б» (рис. С.И. Павлова) 


\section{Список литературы:}

1. Медведев Л.Н., Рогинская Е.Я. Каталог кормовых растений листоедов СССР. М., 1988. 190 с.

2. Каплин В.Г., Перцева Е.В., Антонов П.В. Скрытоживущие насекомые - вредители злаковых культур: монография. М.: Наука, 2007. 230 с.

3. Ланге К.П., Тимофеев В.Е. Методика наблюдений над сезонными явлениями природы. Куйбышев: КГПИ, 1972. $61 \mathrm{c.}$

4. Андрианова Н.С. Экология насекомых: курс лекций. М.: МГУ, 1970. 158 с.

5. Банников А.Г., Рустамов А.К. Охрана природы: Справочник. М.: Колос, 1977. 207 с.

6. Русин Н.П., Флит Л.А. Солнце и хлеб. Л.: Гирометиздат, $1971.167 \mathrm{c}$.

7. Павлов С.И. Этолого-экологические адаптации в процессе проявления превентивной заботы о потомстве у жуков-листоедов (Coleoptera, Chrysomelidae) // Вестник Волжского университета им. В.Н. Татищева. Сер. «Экология». 2011. № 12. С. 72-78.

8. Гуськова Е.В. Особенности биологии и экологии листоедов Oulema melanopus L. в условиях Южного Урала // Вестник Челябинского государственного педагогического университета. Серия 10: Экология. Валеология. Педагогическая психология. 2003. № 4. C. 49-59.

9. Борисенко Н.Х., Смирная Т.П. Изучение устойчивости пшеницы к красногрудой пьявице // Селекция и генетика пшеницы: сб. статей к 80-летию со дня рождения акад. П.П. Лукьяненко. Краснодар, 1982. C. 246-250.

10. Горбунов Н.Н., Рунёва Т.Д., Собакарь Т.А., Тимохина А.Ф. Изменение биомассы личинок пьявицы красногрудой в процессе развития // Вредители зерновых и овощных культур в Западной Сибири: Науч.-технич. бюлл. Вып. 18. Новосибирск: CO ВАСХНИЛ, 1983. С. 7-10.

11. Зайцев Ю.М., Медведев Л.Н. Личинки жуковлистоедов России. М.: ТНИ КМК, 2009. 246 с.

12. Беляев И.М. Вредители зерновых культур. М.: Колос, 1974. 284 c.

13. Обзор распространения вредителей и болезней сельскохозяйственных растений в 1960 г., про- гноз появления их в 1961 г. по Куйбышевской области и рекомендации по защите растений. Куйбышев: Управление СХ КО, 1961. 44 с.

14. Болдырев В.Ф., Бухгейм А.Н., Попов П.В., Савздарг Э.Э., Свириденко П.А., Тупиков В.К. Основы защиты сельскохозяйственных растений от вредителей и болезней. Ч. 2 / под ред. В.Ф. Болдырева. М.: Сельхозгиз, 1936. С. 60.

15. Наумов Н.П. Экология животных: учеб. пособие для гос. ун-тов. 2-е изд. М.: Высш. школа, 1963. $618 \mathrm{c}$.

16. Павлов С.И. Шипоноска черная Hispella atra Linnaeus, 1767 // Красная книга Самарской области. T. 2. Редкие виды животных / под ред. чл.-корр. РАН Г.С. Розенберга и проф. С.В. Саксонова. Тольятти: ИЭВБ РАН; «Кассандра», 2009. С. 141.

17. Павлов С.И. Стратегия и механизмы питания личинок листоедов-щитоносок (Coleoptera, Chrysomelidae, Cassidinae) // Вестник Самарского государственного университета. 2006. № 7 (47). С. 143-147.

18. Коблова Т.А. Сравнительный количественный анализ жуков травостоя на посевах пшеницы в юговосточных районах Оренбургской области // Материалы 3-й зоологической конференции педагогических институтов РСФСР. Волгоград: ВГПИ, 1967. С. 299-301.

19. Медведев Л.Н., Павлов С.И. Фенология и особенности распределения пьявицы красногрудой (Lema melanopus L.) на посевах (пшеницы и овса) разного возраста в условиях Куйбышевской области // Исследования энтомофауны Среднего Поволжья: Межвуз. сб. науч. ст. Т. 243. Куйбышев: КГПИ, 1980 C. $45-52$.

20. Костромитин В.В. Стациальное распределение и трофические связи блошек рода Phyllotreta Chevr. (Coleoptera, Chrysomelidae) в Целиноградской области // Энтомологическое обозрение. 1982. Т. 61, № 1. С. 81-83.

21. Сливкина К.А. Зоны вредоносности и условия, способствующие проявлению вреда от хлебной полосатой блошки // Защита зерновых культур от вредителей, болезней и сорняков в Северном Казахстане: сб. науч. тр. Алма-Ата: Изд-во ВО ВАСХНИЛ, 1982. C. 32-42.

\section{DYNAMICS OF LEAF BEETLES DENSITY (COLEOPTERA, CHRYSOMELIDAE) IN GRAIN CROPS AGROCOENOSES OF THE SAMARA REGION}

(C) 2018

Pavlov Sergey Ivanovich, candidate of biological sciences, associate professor of Chair of Biology, Ecology and Methods of Teaching

Yaitsky Andrey Stepanovich, senior lecturer of Chair of Biology, Ecology and Methods of Teaching Samara State University of Social Sciences and Education (Samara, Russian Federation)

Abstract. The author studied winter and spring wheat (Tríticum) development dynamics in the Volga Region leftbank forest-steppe zone during 1974-2010 in natural conditions and gardens on the Samara Region cereal crops fields, as well as generation cycles of 6 local species of leaf beetles, with 1-year development, 5 of which do a lot of harm to wheat (Oulema melanopus L., Phyllotreta vittula Redt., Chaetocnema aridula Gyll., Chaetocnema hortensis Geoffr., Hispella atra L.) and 1 (Cassida rubiginosa Müll.) is the consumer of a weed plant - Cirsium arvense (L.) Scop.). The author also studied leaf beetles density dynamics and their localization on grain crops of different age. The author studied cereal crops agrocoenoses microclimate under different weather conditions, different plants vegetation intensity at different times of the day. The author also studied major stages of beetles harmful species generation and the timing of their implementation. The paper contains an analysis of the extent and timing of different harmfulness of leaf beetles; the economic value of their separate types. The author surveyed the conditions preferred by the pests of wheat as well as the factors depressing their larval stage and considered the cases of beetles and lar- 
vae massive aggregations formation and beetles migration into more comfortable areas. The author comes to the conclusion of the extraordinary plasticity and adaptability of the leaf to the microclimatic conditions of the habitat.

Keywords: leaf beetle; Chrysomelidae; Oulema melanopus L.; Phyllotreta vittula Redt.; Chaetocnema aridula Gyll.; Chaetocnema hortensis Geoffr.; Hispella atra L.; Cassida rubiginosa Müll.; pests; agrocoenosis; generation cycles; dynamics of density; grain crops; Tríticum L.; Avena L.; Hordeum L.; Samara Region; Middle Volga Region.

УДК $574.472+582.284$

Статья поступила в редакцию 12.04.2018

\section{РЕАКЦИЯ ГРИБОВ-МАКРОМИЦЕТОВ НА АНТРОПОГЕННЫЕ НАРУШЕНИЯ СРЕДЫ} (C) 2018

Сафонов Максим Анатольевич, доктор биологических наук, профессор кафедры общей биологии, экологии и методики обучения биологии Оренбургский государственный педагогический университет (2. Оренбург, Российская Федерация)

Аннотация. В статье рассматривается влияние антропогенного пресса на разные уровни организации биоты грибов-макромицетов: банк спор и пропагул грибов, отдельные грибные организмы и их сообщества. Предполагается, что антропогенные нарушения среды приводят к снижению жизнеспособности спор некоторых грибов и изменению соотношения численностей спор разных видов. Нарушения среды влияют на грибы прямо и косвенно, но более значимыми являются косвенные воздействия, поскольку уничтожение плодовых тел не влияет на состояние мицелия. К косвенным воздействиям относятся нарушение физико-химических свойств субстратов (почва, древесина), увеличение их токсичности, изменения растительного покрова, обусловливающие изменение качественных и количественных характеристик детрита и растений, способных формировать микоризу. Обсуждаются механизмы снижения разнообразия и функционирования микобиоты в условиях техногенного загрязнения. Сообщества грибов реагируют на антропогенные нарушения путем изменения структуры, в особенности - функциональной, что выражается в увеличении абсолютной и относительной численности фитопатогенных грибов в сообществах. Делается вывод, что современная тенденция развития региональной микобиоты направлена на сохранения естественного состояния и в настоящее время явные признаки ее деградации отсутствуют.

Ключевые слова: антропогенные нарушения; грибы-макромицеты; банк спор; микоценоз; микобиота; поллютанты; фактор субстрата; структура сообщества; концентрация доминирования; фитопатогенные грибы; устойчивость; Оренбургская область.

\section{Введение}

Динамика биологических систем надорганизменного уровня имеет разные масштабы и интенсивность. Так, сукцессионная динамика представляет собой необратимые перестройки структуры сообществ, вызванные внешними или внутренними причинами; флуктуации разной амплитуды и периодичности - колебания структурных показателей в зависимости от соответствующих изменений климатических условий; эволюция сообществ - закономерная трансформация в соответствии с общим ходом развития биосферы. С появлением и развитием деятельности человека все большее распространение и влияние на состояние биосферы приходится на долю нарушений - скачкообразных изменения сообществ в результате резкого изменения условий среды (чаще всего инспирированных человеком).

Антропогенные нарушения среды имеют глобальное распространение и оказывают влияние на все компоненты биогеоценозов - микробоценозы, микоценозы, фитоценозы, зооценозы. Если говорить о формах нарушений, то ведущая роль принадлежит косвенным воздействиям на экотопы - изменениям физико-химических условий среды обитания и субстратов, химизма трофических ресурсов и т.п., что приводит в итоге к нарушению функционирования отдельных звеньев пищевых цепей и трансформации структуры сообществ и биогеоценоза в целом. Прямое уничтожение особей вследствие нарушений также имеет место в современной природе; чаще всего оно связано с уничтожением местообитаний вследствие хозяйственной деятельности человека (распашка, вырубка леса, разработка полезных ископаемых, строительство и др.).
Сообщества, оказывающиеся в нарушенных условиях, обладают определенной толерантностью в отношении антропогенной нагрузки вплоть до определенного уровня пресса. Особи разных видов, входящих в сообщество, по-разному реагируют на непредвиденную экстремализацию условий существования: некоторые из них способны пережить неблагоприятные перемены благодаря временному снижению своей активности или перестройке функционирования, другие интенсифицируют свою жизнедеятельность вследствие снижения конкуренции со стороны первых видов, часть видов гибнет или переходит в латентное состояние.

Знание закономерностей реакции разных организмов на нарушения среды является инструментом понимания закономерностей трансформации сообществ при антропогенном прессе, а также основой для прогнозирования структурных перестроек при тех или иных формах нарушений.

Цель данной работы - обобщение данных, собранных в 2004-2017 гг. в пределах Оренбургской области, о реакции грибов-макромицетов на антропогенные нарушения.

\section{Материалы и методы исследований}

Использованы данные многолетних исследований видового состава и структуры биоты грибов-макромицетов, проведенных в 20 административных районах Оренбургской области, расположенных в лесостепной и степной зонах Южного Предуралья. Всего обследовано более 500 га лесов разного типа и собрано более 7 тыс. образцов плодовых тел грибов с последующей идентификацией их видовой принадлежности. При описании систематического положе- 